\title{
An econometric analysis for food security in Tunisia
}

\author{
Houcine Jeder*, Sabrine HattaB**, Iheb FriJA***
}

DOI: $10.30682 / \mathrm{nm} 2004 \mathrm{a}$

JEL codes: C01, O13, Q18

\begin{abstract}
Food security issue is getting more attention in middle-income countries such as Tunisia after the revolution 2011, where many factors affecting its food security are multiplied. An econometric analysis of food security was done through the Vector Error Correction Model approach (VECM). The result of this approach shows that there is a significant long-term causality between the dependent variables and the explanatory variables. Some signs of variables like land under cereals assert the hypothesis of Ricardo's land rent theory and also attract attention for the preservation of land fertility in climate change context. However, there is a short-term causal relationship between food security and independents variables like: land under cereals, inflation and food imports. These results confirm that the issue of food security in Tunisia is a question of threat in the short and long-term instability. So, it is important today to readjust some factors to ensure food security in Tunisia like controlling inflation and lowering the food importation as short-term measures and preserving and improving the fertility of land under cereals and adopting climate change as long-term measures.
\end{abstract}

Keywords: Food security, Threat factors, Econometric analysis, Tunisia.

\section{Introduction}

Food security is a global issue that encompasses all three spheres of sustainability; environment, social and economic. It is not about scarcity, because there is enough food worldwide, but is about the reliable access to sufficient and nutritious food. There are three pillars of food security; availability, access and utilisation (Figure 1), (Van Eldik, 2012). Interruptions to any of the components will lead to food insecurity affecting food supply and market prices. Stabilisation can be affected by various causes such as climate change, water supply, pest and disease management and the economic environment.
Maintaining stability among the three pillars of food security is essential for ensuring continuous food supply (Coates, 2013; Barrett, 2010).

Figure 1 - Three pillars of food security.

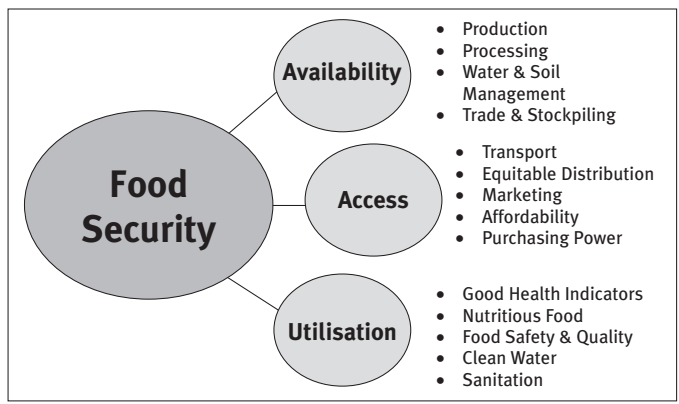

\footnotetext{
* Regional Center of Research in Horticulture and Organic Agriculture (CRRHAB), Sousse / Laboratory of economy and rural communities, Arid Regions Insitut (IRA), Medenine, Tunisia.

** Regional Researches Center on Horticulture and Organic Agriculture (CRRHAB), Sousse, Tunisia.

*** Higher Agronomic Institute Chott Mériem (ISA CM), Sousse, Tunisia.

Corresponding author: djederhoucine@yahoo.fr
} 
The food security can also be interpreted as a multidimensional and dynamic issue in the short and long term. Solving this problem requires taking into account the specificities of the development model and food strategies in the country. The question of food security was behind the failure of the Tunisian model of development by a social revolution in January 2011. According to the report of the Food and Agriculture Organization (FAO), world food prices reached a record high in January 2011, exceeding the levels reached during the 2007-2008 food crisis. As several analysts have shown, the extreme vulnerability to rising food prices of most countries of North Africa was undoubtedly a precipitating condition for social unrest (Bellemare, 2011; Breisinger et al., 2011; Lagi et al., 2011; World Bank, 2011). Despite the contribution of the Green Revolution and the integration of technology in increasing agricultural production, food security remains a fundamental problem for many countries around the world. The shortage of agricultural products on international markets and the large fluctuations in food prices clearly reflect the tensions between demand and supply, thus causing higher prices and food insecurity in Mediterranean countries (Lacirignola et al., 2015). A recent IFPRI report asserts that "food security has deteriorated in most Arab countries, which is consistent with observed high food prices inflation" and that, particularly in Tunisia. The diminishing capacity of the largest fraction of the population to access staple food and, more generally, the increased inability of the state to hamper the erosion of household incomes has been no doubt an important factor in crystallizing social discontent in North Africa (Breisinger et al., 2011). With this regard, the assertion that the food issue has taken a political dimension should not be understood in a restrictive way, i.e. that increases in food prices are likely to generate food riots and social unrest, but rather that they can lead, as was the case in Tunisia, to the rejection of the entire socio-political system (Gana, 2012). The farmers' protest movement in Tunisia highlights the need for governments to address the social and food security dimension of agricultural development and call for structural reform in land resource allocation, for major transformations in the social and technical models of agricultural production (IAASTD, 2009), as well as for profound changes in the organization of farm input and output markets, at various scales. Finally, the lesson to be learned from the Tunisian case is the profound link between all these factors: social, economic, agricultural and natural resources. The failure of the political system and the development model may worsen the issue of food security in the coming years in Tunisia with the context of climate change, where the Mediterranean regions will be the most affected by this phenomenon and in particular the developing countries.

The initiation of the study or research on the issue of food security must refer mainly to the basic definition of this concept. During the Rome Declaration on World Food Security in 2002, FAO defined food security as when "all people, at all times, have physical, social and economic access to sufficient, safe and nutritious food that meets their dietary needs and food preferences for an active and healthy life" (Belloumi, 2014). This definition explains that food security exists when people, at all times, have access to adequate, safe and nutritious food that meets their dietary needs and food preferences for an active and healthy life (Ojo, 2004). So to address the issue of food security, one must consider the key dimensions in this definition like: availability, stability, access, and utilization (ADB, 2012; Kumar and Sharma, 2013). Several studies and research work have been carried out on the issue of food security and their dimensions in several regions of the world, but in Tunisia, the work remains somewhat limited with a descriptive and qualitative analytical approach. This study will address the issue of food security in a quantitative way by trying to identify the determinants of food security in Tunisia reflecting the key dimensions through an econometric approach adequate to this issue for interesting policy and strategic recommendations.

The study is structured in sections: after the introduction, we present a brief review of the literature on the methodological approach adopted to analyze the issue of food security. Then, a representation of the empirical model used in the study followed by an empirical result of the 
estimation techniques and a discussion. At the end, a conclusion summarizes some recommendations for policy makers in terms of food security policy.

\section{Literature Reviews}

There are several research studies dealing with the problem of food security. Some studies focus on the determinants of the household-level food security model, for others at the national level depending on their intended objectives. The determinants of food security remain the main question of several researches despite the diversity of scales. The national scale remains the most favorable scale for the strategic orientation of policy makers. For example, in Morocco, according to Aker and Lemtouni (1999), there are many factors that affect the Moroccan food security model, namely national food production, rainfall, food prices, Gini coefficient of income distribution, exports, female illiteracy rate and local health environment. Other studies have shown the impact of population growth on food security. Similarly, household size is one of the important determinants of food security at the household level, and empirical results show that household size is significant and negatively related to food security (Mensah et al., 2013). Another study showed that household size for food insecurity at the household level gives a significant and positively related result (Gebre, 2012). On the other hand, the household size was important but had a negative impact on the food insecurity of rural households in Africa (Amaza et al., 2008).

Climate change has also become another important factor to be included in the food security model. Recent research has examined the impact of climate change on major components of food security such as availability, accessibility, affordability, preference, utilization, and nutritional value and food system stability. It is expected that the viability of current world agro-ecosystem and future food availability have long term implication (Edame et al., 2011). Climate change tend to reduce agriculture productivity, production stability and income in some areas that already have high food security.
Tunisia is like other countries in the world, the issue of food security is a priority for agricultural and agri-food policies of countries. The way scientists and researchers and policy makers analyzed this issue was not within the same approach. Scientists focused on specific issues in relation to their skills and expertise specialties while policy makers focused on development policies and regulatory instruments to ensure food security. Food security in Tunisia was often linked to the agriculture sector. This relationship is obvious, since food production was always the output of agricultural activity, but when the agricultural development model ended in deadlock and reached its limits, food security will be the most affected and the repercussions will be great magnitudes on the social and economic life in the country (Lattre-Gasquet et al., 2017).

The issue of food security has been addressed in many ways and on several scales. For some, the national scale is important because food security depends on trade and international exchange and world prices, so the macro-level study is the most appropriate for raising the gaps in food security and country sovereignty in terms of food. Among these works, we can note the paper that addressed the issue of food security at the Maghreb scale through a comparative approach to provide a review of the agricultural policies performance in the jive countries in the Maghreb and examine results of the reforms that have been taking place in these countries to achieve food security (Chebbi and Lachâal, 2004).

Other papers linked the problem of food security to water resources, particularly the concept of virtual water through an analysis of the evolution of food and nutritional security in Tunisia, evaluating its sustainability under conditions of scarcity and free trade areas, with particular emphasis on the meat sector and the impact of climate change on agricultural production (Ouertani et al., 2016). Nutrition is also likely to be affected by climate change through related impacts on food security, dietary diversity, care practices and health. Indeed, climate change is a serious threat to food security if necessary measures are not taken by policy makers (Krishnamurthy et al., 2012). 
The majority of these papers on food security are based on a descriptive and qualitative analysis approach on the main dimensions related to the concept of food security in a separate way: availability, access, stability and use in terms of quality and food safety. The search for an integrated, quantitative and explanatory approach remains the most appropriate approach to identify the determinants of food security in Tunisia.

The quantitative approach and in particular the econometric one is an appropriate approach for this type of problems, but the integration of the different dimensions of food security and the influencing factors through the choice of variables remains the most interesting task. This paper will adopt this econometric approach as a methodological tool of analysis to identify the key factors of food security in Tunisia, and the main recommendations that can be drawn to build strategic orientations for agri-food policies on this vital issue.

\section{Data and Methodology}

\subsection{Data}

The variables of food security used in this study during the period of 1991-2017 are:

- Food production index (2004-2006=100) which is proxy of food security. This index covers food crops that are considered edible and that contain nutrients. Coffee and tea are excluded because, although edible, they have no nutritive value.

- Inflation, consumer prices (annual \%) as measured by the consumer price index reflects the annual percentage change in the cost to the average consumer of acquiring a basket of goods.

- Food imports (\% of merchandise imports); food comprises the commodities in $\mathrm{SITC}^{1}$ sections 0 (food and live animals), 1 (beverages and tobacco), and 4 (animal and vegetable oils and fats) and SITC division 22 (oil seeds, oil nuts, and oil kernels).
- Land under cereal production (hectares) refers to harvested area, although some countries report only sown or cultivated area. Cereals include wheat, rice, maize, barley, oats, rye, millet, sorghum, buckwheat, and mixed grains. Production data on cereals relate to crops harvested for dry grain only. Cereal crops harvested for hay or harvested green for food, feed, or silage and those used for grazing are excluded.

- Population, total is based on the de facto definition of population, which counts all residents regardless of legal status or citizenship. The values shown are midyear estimates.

- Precipitation $(\mathrm{mm})$ is the average precipitation in depth (mm per year).

- Temperature $\left(c^{\circ}\right)$ is the average temperature per year.

All these variables are expressed in long terms. Those data obtained from World Bank and Department of Statistic (DOS) but for the precipitation and temperature from basic data of National Institute of Metrology (INM).

\subsection{Model Specification}

Food security is defined in terms of four components: food availability, access to food, food use, and food stability (FAO, 2006). Food production indicates that food available for the population is produced by a country through national food production, alone or beyond domestic food production or both (Aker and Lemtouni, 1999). National food production is the largest quantitative component of national food security for almost all countries (FAO, 1996). Lack of food will cause hunger and famine in a country. Therefore, the empirical outline will be used for food production as an indicator of food security.

Based on the discussion on the potential determinants of food security, the model can be written as following:

$F P I=F(I N F, L C E R, F I M P, P O P, P R C, T E M P)$

\footnotetext{
${ }^{1}$ Standard International Trade Classification (SITC) is a classification of goods used to classify the exports and imports of a country to enable comparing different countries and years. The classification system is maintained by the United Nations. The SITC classification is currently at revision four, which was promulgated in 2006.
} 
In log terms the equation (1) becomes as follows

$$
\begin{gathered}
\ln F P I=\alpha_{0}+\alpha_{1} \ln I N F_{t}+\alpha_{2} \ln \mathrm{LCER}_{t}+ \\
\alpha_{3} \ln F I M P_{t}+\alpha_{4} \ln \mathrm{POP}_{t}+\alpha_{5} \ln \mathrm{PRC}_{t}+ \\
\alpha_{6} \ln \mathrm{TEMP}_{t}+\varepsilon_{t}
\end{gathered}
$$

\section{Where}

$F P I=$ Food production index $(2004-2006=100)$ $I N F=$ Inflation, consumer prices (annual \%)

$L C E R=$ Land under cereal production (hectares) $F I M P=$ Food imports ( $\%$ of merchandise imports) $P O P=$ Total population

$P R C=$ Precipitation $(\mathrm{mm})$

TEMP $=$ Temperature $\left(\mathrm{c}^{\circ}\right)$

$\alpha_{0}, \alpha_{1}, \alpha_{2}, \alpha_{3}, \alpha_{4}, \alpha_{5}$, = Coefficient for the explanatory variables

$\varepsilon=$ error term and $t=$ times series period

The food security model analysis is based on tests and econometric techniques. The unit root test, co-integration test, and error correction model (ECM) techniques have been used for analyzing the time series data. The unit root test is called the Augmented Dickey-Fuller (ADF) test. First, the results show that food security and all the explanatory variables are stationary in the first difference value.

Second, the goal is to examine the long run relationship between food security and its determinants through the normalized co-integrating equation showing that all the variables are significant in the long run.

Further, the data were analyzed using the Vector Error Correction Model (VECM) to determine how much the short run deviated from the long run. The coefficient in error correction term (ECT) is the speed of adjustment factor. There exists one error correction term in this analysis. The result shows the value of ECT is negative and significant indicated that there is long run causality between food security and its determinants.

Then, the diagnostic tests were conducted. These tests consist of the normality test (Jarque-Bera). In the Breusch-Godfrey Serial Correlation LM Test, we conclude that there is no evidence of autocorrelation problem in the model. And finally, in the heteroscedasticity test we conclude that there is no evidence of heteroscedasticity problem in the model. To conclude, we can say that the specification of the food security model does not represent statistical anomalies and the representation of this model is acceptable.

\subsection{Unit Root Test}

All the variables used in this food security model are tested for stationarity using unit root test. Testing of the stationarity of the time series ensures that the variables used in the analysis are not subjected to spurious correlation should be done before the estimation of the econometric model. The time series properties of the variables used in this study are the standard Augmented Dickey-Fuller (ADF) test.

The ADF test is given by:

$$
Y_{t}=\alpha_{1}+\alpha_{2} Y_{t-1}+\mu_{t} \quad t=1,2,3 \ldots \ldots
$$

\section{Where}

$Y_{t}=$ variable $\mathrm{y}$ at time $\mathrm{t}$

$Y_{t-1}=$ variable $\mathrm{y}$ at legged $\mathrm{t}$

For convenient unit root testing, the equation is subtracted by $\mathrm{Yt}-1$ and we have equation (4):

$\Delta Y_{t}=\beta_{t}+\beta_{2} \Delta Y_{t-1}+\varepsilon_{t} \quad$ and $\beta_{2}=\rho-1$

The hypothesis for unit root test is as following:

$\mathrm{H}_{0}: \beta_{2}=0 ; y_{t}$ is non-stationary

$\mathrm{H}_{1}: \beta_{2}<0 ; y_{t}$ is stationary

\subsubsection{Johansen co-integration test and long run equilibrium}

Johansen test is used to test for co-integration in times series. The purpose of this test is to examine the long run relationship between the dependant variable and explanatory variables in the food security model. This test is carried out when all of the variables appeared to be co-integrated at the same order. In this 
study, the focus is to determine the long run relationship between food security and the determinant.

The Johansen tests are likelihood-ratio tests. There are two tests: (1) the maximum eigenvalue test, and (2) the trace test. For both test statistics, the initial Johansen test is a test of the null hypothesis of no co-integration against the alternative of co-integration. The test differs in terms of the alternative. The null hypothesis for the eigenvalue test is $r=$ equals the number of co-integration vectors in the model, while the null hypothesis for trace test is $r \leq$ the number of co-integration vectors in the model. Similar to the unit root test, the number of co-integration vectors could be constant or include a trend term or both. This approach will later be used to examine the long run impact of the explanatory variables on food security.

\subsection{Vector Error Correction Model (VECM)}

The Vector Error Correction Model (VECM) technique is used when the variables in the Vector Autoregressive Models (VAR) are co-integrated. Granger representation theorem defined that when variables are co-integrated, there must also be an Error Correction Term (ECT) that describes the short run dynamics or adjustments of the co-integrated variables towards their equilibrium values. One period lagged co-integrating equation and the lagged first differences of the endogenous variables ECT consists in ECT. One can estimate ECT by using the Restricted Vector Autoregression (VAR) method. In particular, the Error Correction Model (ECM) can be constructed by expressing changes in the dependant variables as a function of the level of disequilibrium in the co-integrating relationship (captured by the ECT) as well as changes in other explanatory variables. This approach will show the speed of adjustment of the model in short run. Equation (5) shows the error correction model developed:

$$
\begin{gathered}
\Delta \ln F P I=\alpha_{0}+\alpha_{1} \Delta \ln I N F_{t}+\alpha_{2} \Delta \ln L C E R_{t}+ \\
\alpha_{3} \Delta \ln F I M P_{t}+\alpha_{4} \Delta \ln P O P_{t}+\alpha_{5} \Delta \ln P R C_{t}+ \\
\alpha_{6} \Delta \ln T E M P_{t}+\alpha_{7} E C T_{t-1} \delta_{t}
\end{gathered}
$$

\section{Where}

$E C T_{t-1}$ is the Error Correction term and $\delta$ are the random error term.

\section{Results and Discussions}

The results of ADF unit root test show that at level, $\mathrm{t}$-statistic values for all the variables used in this study such as food production index $(\ln F$ $P I)$, consumer prices $(\ln I N F)$, land under cereal production $(\ln L C E R)$, food imports $(\ln F I M P)$, total population $(\ln P O P)$, precipitation $(\ln P R C)$ and temperature (InTEM) are not statistically significance. Then, null hypothesis of non-stationary cannot be rejected at any significant level indicates that all variables series are non-stationary at level and the series contain a unit root.

However, at first difference, t-statistic values are significant. So, the null hypothesis of non-stationary can be rejected indicates that all variables are stationary at first different. Therefore, the result means that all the series are integrated of order one, I (1). Since the variables in the model are I (1), the spurious regression problem occurs.

Since the variables in the model are I (1), the spurious regression problems occur. Thus, the following sections discuss the results of co-integration analysis. The discussion starts with the determination of the optimal lag length obtained based on the VAR lag order selection criteria. The results in the Table 2 show that the optimal lag length for co-integration is 1 .

The Johansen co-integration test conducted since unit root test showed that all the variables are I (1) and stationary at same order. Johansen test is purposely used to see the long run relationship between two or more variables in the model. There are two co-integration tests conducted such as trace test and max-eigenvalue test and both tests used linear deterministic trend with restriction, the result is presented in Table 3.

The co-integration test results both based on Trace statistic and Max-eigenvalue indicates 2 co-integrating equations at the $5 \%$ level. Both results indicate that the variables are co-integrated each other and there is a long run significant relationship at the $1 \%$ level between food production index and explanatory variables (Table 4). 
Table 1 - Unit root tests of stationarity.

\begin{tabular}{|c|c|c|c|c|c|}
\hline Variable & $\begin{array}{c}\text { Level } \\
\text { Intercept }\end{array}$ & $\begin{array}{c}\text { Intercept \& } \\
\text { Trend }\end{array}$ & $\begin{array}{c}\text { Level } \\
\text { Intercept }\end{array}$ & $\begin{array}{l}\text { First Difference } \\
\text { Intercept \& Trend }\end{array}$ & Results \\
\hline $\operatorname{lnFPI}$ & $\begin{array}{c}-0.607389[2] \\
(0.8506)\end{array}$ & $\begin{array}{c}-5.923766[0] \\
(0.0003)^{* * *}\end{array}$ & $\begin{array}{c}-5.923766[5] \\
(0.0002)^{* * *}\end{array}$ & $\begin{array}{c}-5.497041[5] \\
(0.0016)^{* * *}\end{array}$ & I (1) \\
\hline $\operatorname{lnINF}$ & $\begin{array}{c}-2.258717[1] \\
(0.1924)\end{array}$ & $\begin{array}{c}-2.398042[1] \\
(0.3711)\end{array}$ & $\begin{array}{c}-8.836484[0] \\
(0.0000)^{* * *}\end{array}$ & $\begin{array}{c}-9.022543[0] \\
(0.0000)^{* * *}\end{array}$ & I (1) \\
\hline lnLCER & $\begin{array}{c}-4.919469[0] \\
(0.0006)\end{array}$ & $\begin{array}{c}-4.812466[0] \\
(0.0038)\end{array}$ & $\begin{array}{c}-7.230797[0] \\
(0.0000)^{* * *}\end{array}$ & $\begin{array}{c}-3.912758[5] \\
(0.0323)^{* *}\end{array}$ & I (1) \\
\hline $\operatorname{lnFIMP}$ & $\begin{array}{c}-3.451598[0] \\
(0.0185)^{* *}\end{array}$ & $\begin{array}{c}-3.538415[0] \\
(0.0568)\end{array}$ & $\begin{array}{c}-7.131453[0] \\
(0.0000)^{* * *}\end{array}$ & $\begin{array}{c}-4.762357[1] \\
(0.0048)^{* * *}\end{array}$ & I (1) \\
\hline $\ln \mathrm{POP}$ & $\begin{array}{c}-0.868312[4] \\
(0.7778)\end{array}$ & $\begin{array}{c}-4.639239[5] \\
(0.0076)\end{array}$ & $\begin{array}{c}-4.737478[5] \\
(0.0015)^{* * *}\end{array}$ & $\begin{array}{c}-4.691917[5] \\
(0.0074)^{* * *}\end{array}$ & I (1) \\
\hline $\ln P R C$ & $\begin{array}{c}-4.919469[0] \\
(0.0001)^{* * *}\end{array}$ & $\begin{array}{c}-5.573624[0] \\
(0.0007)^{* * *}\end{array}$ & $\begin{array}{c}-9.123293[0] \\
(0.0000)^{* * *}\end{array}$ & $\begin{array}{c}-9.009635[5] \\
(0.0000)^{* * *}\end{array}$ & I (1) \\
\hline lnTEMP & $\begin{array}{l}0.551581[0] \\
(0.9851)\end{array}$ & $\begin{array}{c}-0.797104[0] \\
(0.9525)\end{array}$ & $\begin{array}{c}-1.818440[1] \\
(0.3630)\end{array}$ & $\begin{array}{c}-3.962758[0] \\
(0.0422)^{* *}\end{array}$ & I (1) \\
\hline
\end{tabular}

Notes:

*** Indicates the rejection of hypothesis null of non-stationary at $1 \%$ of significant.

** Indicates the rejection of hypothesis null of non-stationary at $5 \%$ of significant.

* Indicates the rejection of hypothesis null of non-stationary at $10 \%$ of significant.

[] Indicates the lag specification. () Indicates prob. value.

Table 2 - VAR lag order selection criteria.

\begin{tabular}{|c|c|c|c|c|c|c|}
\hline Lag & $\log L$ & $L R$ & $F P E$ & $A I C$ & $S C$ & $H Q$ \\
\hline 0 & 98.81265 & NA & $1.52 \mathrm{e}-12$ & -7.345012 & -7.003727 & -7.250354 \\
\hline 1 & 250.2652 & $205.9754^{*}$ & $4.94 \mathrm{e}-16^{*}$ & $-15.54121^{*}$ & $-12.81093^{*}$ & $-14.78395^{*}$ \\
\hline
\end{tabular}

Notes:

* Indicates lag order selected by the criterion at 5\% level of significant.

LR: Sequential modified LR test statistic. - FPE: Final prediction error. - AIC: Akaike information criterion.

$S C$ : Schwarz information criterion. - HQ: Hannan-Quinn information criterion.

Table 3 - Co-integration test results.

\begin{tabular}{|c|c|c|c|c|}
\hline $\begin{array}{c}\text { Hypothesized No. of } \\
\text { CE(s) }\end{array}$ & Trace Statistic & 0.05 Critical Value & Max-Eigen Statistic & 0.05 Critical Value \\
\hline None $^{*}$ & 225.5030 & 125.6154 & 95.51207 & 46.23142 \\
\hline At most $1 *$ & 129.9909 & 95.75366 & 62.51220 & 40.07757 \\
\hline At most 2 & 67.47874 & 69.81889 & 25.39003 & 33.87687 \\
\hline
\end{tabular}

Notes:

Trace test indicates 2 cointegrating eqn(s) at the 0.05 level.

Max-eigenvalue test indicates 2 cointegrating eqn(s) at the 0.05 level.

* denotes rejection of the hypothesis at the 0.05 level. 
Table 4 - Results of co-integration equation.

Co-integration equation

Log likelihood 280.1063

Normalized co-integrating coefficients ( $t$-Student in parentheses)

\begin{tabular}{|c|c|c|c|c|c|c|}
\hline LFPI & LCPI & LLCER & LPOP & LFIMP & LPRC & LTEMP \\
\hline 1.000000 & -3.463718 & -3.030863 & -14.15710 & -13.87866 & 8.257720 & -22.27614 \\
\hline & $-4.5723 * * *$ & $-7.7876^{* * *}$ & $-5.3058^{* * *}$ & $-15.513^{* * *}$ & $12.224 * * *$ & $-2.896 * * *$ \\
\hline
\end{tabular}

Note: *** Significant at the 1\% level.

This relationship between these dependent and independent variables supports our hypothesis that food insecurity in Tunisia is a long-term problem and that some factors pose a threat to food security. It is therefore important to take corrective measures or adjustments to maintain and improve food security. Negative signs of some variables in the Table 4 are expected, such as: INF (inflation), POP (population), and FIMP (food import). And several works show these results (Warr, 2014) and (Amjath-Babu et al., 2019).

The negative sign of the climatic variable, such as the temperature variable (TEMP), confirms that climate change will have adverse effects on food security due to the instability and decline in agricultural production of some crops important for food security, such as the cereals. While, the precipitation variable (PER) will have positive effects on agricultural production and productivity. These signs of long-term climatic variables do not differ from the results found in other research on the relationship between food security and climate change (Khee et al., 2011; Alam et al., 2011).

The negative sign of the variable of land under cereal production (LCER) is not expected as increasing cereal areas normally contribute to increase agricultural production and food security. But we can find explanations for the negative sign of the variable (LCER) in the classical theory of Ricardo land rent (Ricardo, 1815), which decreases because the extension extends to less fertile marginal lands or is already fully cultivated (Bidard, 2014). This variable also explains the negative sign of the population variable $(P O P)$, indeed, to feed a population it is necessary to extend on land even less fertile marginal lands, and the famous economist Malthus explains this question by the difference between the population with experiential growth and food supplies with arithmetic growth due to this decrease in land rent (Malthus, 1815).

Finally, we can deduce from the co-integration equation that food security is threatened in the long term and that the significant signs of the different variables of the model find these explanations in classical economic theory and the impacts of climate change.

Thus, it would be inappropriate to estimate a VAR model when the variables are co-integrated and expressed in first differences (Baffoe-Bonnie and Gyapong, 2012) because first differencing would lead to the loss of a significant portion of information related to the co-movement in the data. Rather than a VAR model, an error correction model is the appropriate model if the variables are co-integrated in first differences (Engle and Granger, 1987). According to Engle and Granger (1987), the co-integration relationship must have an ECM representation. The ECM essentially estimates the short run dynamics between the variables. The results of short run Error Correction Model for food security is presented in Table 5.

Based on the VECM result in the Table 5, an error correction term exists in this analysis. Since the coefficient value of this error correction term is more than one (ECTt-1>1), it indicates that the short run deviation goes on rapid paths to equilibrium in the long run. Otherwise, if the coefficient value in this error correction term is less 
Table 5 - Results for estimated Vector Error Correction Model (VCEM).

\begin{tabular}{|l|c|c|c|}
\hline \multicolumn{1}{|c|}{ Variables } & Coefficient & t-statistic & Prob. \\
\hline Constant & -0.013713 & -0.141989 & 0.8891 \\
\hline$\Delta$ In FPI $_{\mathrm{t}-1}$ & 0.184697 & 0.707512 & 0.4909 \\
\hline$\Delta$ In CPI $_{\mathrm{t}-1}$ & $\mathbf{- 1 . 8 4 1 6 4 0}$ & $\mathbf{- 2 . 9 5 4 3 3 4}$ & $\mathbf{0 . 0 0 8 4} * * *$ \\
\hline$\Delta$ In LCER $_{\mathrm{t}-1}$ & $\mathbf{0 . 5 3 4 7 3 9}$ & $\mathbf{1 . 8 2 6 1 1 5}$ & $\mathbf{0 . 0 4 9 2 * *}$ \\
\hline$\Delta$ In FIMP $_{\mathrm{t}-1}$ & $\mathbf{- 1 . 7 5 1 3 3 5}$ & $\mathbf{- 2 . 0 7 3 6 5 3}$ & $\mathbf{0 . 0 3 2 3} * *$ \\
\hline$\Delta$ In POP $_{\mathrm{t}-1}$ & 3.193411 & 0.410372 & 0.6877 \\
\hline$\Delta$ In PRC $_{\mathrm{t}-1}$ & 0.164230 & 0.989621 & 0.9792 \\
\hline$\Delta$ In TEMP $_{\mathrm{t}-1}$ & -2.070064 & -1.075262 & 0.3004 \\
\hline FPI & $\mathbf{- 0 . 7 8 5 1 7 6}$ & $\mathbf{- 3 . 4 9 7 6 1 6}$ & $\mathbf{0 . 0 0 3 6 * * *}$ \\
\hline R-squared & 0.745817 & & \\
\hline F-statistic & 4.564281 & & \\
\hline Prob(F-statistic) & 0.005803 & & \\
\hline
\end{tabular}

Notes: *** Significant at the 1\% level; ** Significant at the $5 \%$ level.

than one $($ ECTt- $1<1)$, it indicates that the error correction term slowly adjust back to equilibrium in the long run. The results presented show that the ECTt-1 coefficient is negative and significant at $1 \%$ significant level implying that the series cannot drift too far apart and convergence is achieved at the long run. The estimated coefficient of the error correction term was -0.785176 indicates that the speed of adjustment is around $78 \%$ at $1 \%$ significant level. It means that the adjustment process of the disequilibrium is a bit slowly; it is about $78 \%$ in one year (annually data). Therefore, the representative variables of food security in Tunisia show an overall significance of $74 \%$ at a confidence level of $1 \%$ in the Table 5 (R-squared $=0.745817$; Prob (F-statistic) $=0.005803$ ).

The results also show the existence of significant short-term relationships between food security through proxy food production and explanatory variables. We note that the variable of land under cereal production (LCER) is the only significant positive variable in the short term. This variable positively affects food production in the short term. A $1 \%$ increase in $\Delta \ln L C E R_{t-1}$ will result in $\Delta \log F P I_{t-1}$ expansion of $0.534739 \%$. In terms of significant level, $\triangle \ln L C E R_{t-1}$ is statistically significant at a confidence level of $5 \%$.

This result confirms again the Ricardo hypothesis and also the concept of decreasing marginal productivity of the land. Indeed, it can be deduced that the intensification on land under cereal production (LCER) in Tunisia is increasing but the agricultural productivity could be decreasing in the long term. The change of sign of this variable between the short and long term draws the attention for policy makers in agriculture to seek a strategy of preservation of the land under cereal production and improvement of their fertility especially with the context of climate change.

On the other hand, the other variables showed a significantly negative relationship in the short 
term. It is noted that the inflation variable (INF) has a negative impact on food security. A $1 \%$ increase in $\Delta \operatorname{lnINF}_{t-1}$ will result in $\Delta \ln F P I_{t-1}$ expansion of $0.534739 \%$. In terms of significant level, $\Delta \ln L C E R_{t-1}$ is statistically significant at a confidence level of $1 \%$. This result asserts that inflation is a factor in the deterioration of purchasing power and consumer basket, and its effects will be passed on to agricultural production since demand is low because of rising food prices and high inflation. The Tunisian citizen is in difficulty to provide his staple food and food security will be threatened. The result also confirms the current situation after revolution, especially the period between 2014 and 2017, when the inflation rate reached $6 \%$. The adverse effects of inflation on food security in the short term require regulatory and price control measures and channel the agri-food chain for some staple crops to food.

The second variable is the food imports variable, which has a significant negative effect in the short term. A $1 \%$ increase in $\Delta \ln$ IIMP $_{t-1}$ will result in $\Delta \log F P I_{t-1}$ expansion of $0.534739 \%$. In terms of significant level, $\triangle \operatorname{lnFIMP} P_{t-1}$ is statistically significant at a confidence level of $1 \%$. This result shows that food imports are a disincentive for domestic production and also a factor in increasing the cost of production and also in the price of certain food products. Importation is also a source of depreciation of the national currency (Tunisian dinars) and the deterioration of the purchasing power of Tunisians. Therefore, food security requires slowing down the pace of feed imports and encouraging domestic production through incentive and subsidy strategies. Food security requires investment in new technologies to increase agricultural productivity but without compromising the intensive degradation of natural water and soil resources.

In addition to the relevant findings on the determinants of food security, the validation of the applied VCEM model shows the absence of any statistical anomalies for the series of variables chosen according, so the model is statically good and the choice of variable is statistically acceptable and relevant in terms of results and interpretations.

\section{Conclusions and Recommendations}

Food security in Tunisia is a major issue of great importance for the daily life of Tunisians, especially citizens who have an average income. This problem will worsen with the context of climate change in future years.

The purpose of this study is to determine the influence of certain variables on the food security model of Tunisia. Many variables can play a role for food security in the country. The variables selected for the analysis concerned inflation, population, land under cereals, food imports and the climate variable via precipitation and temperature. These six independent variables have been tested to determine their effect on Tunisia food security model. This study uses time series data from 1991 to 2017.

The result shows that three variables such as inflation, land under cereals and food imports are significant in the short term. Others variables such as climate change and population are neither significant nor important to explain Tunisia's food security in the short term. All variables are significant in the long run at the $1 \%$ level. The result also shows that the TCE- 1 coefficient is negative and significant at the $1 \%$ level, which implies that the series can not deviate too much and convergence is obtained in the long term. The estimated coefficient of the error correction term was 0.78 indicates that the speed of adjustment is about $78 \%$ to $1 \%$ significant level. This means that the imbalance adjustment process is about $78 \%$ in one year.

Based on the results of the study, several recommendations can be made concerning the signs of variables in the equation of long-term and short-term estimates. Indeed, the change in the sign between the short and long term of the variable land under cereals shows that a decline in soil fertility and land rent is decreasing with the context of climate change in accordance with Ricardo's theory. The positive sign of the variable precipitation shows the importance of this variable in food production and also confirms the impact of climate variables on the stability of food security evoked by other research on this issue (Barnett, Adger, 2007; Barrios et al., 2008). Other significant variables having signif- 
icant negative effects are short-term and longterm food production such as inflation and food imports. On one hand, other variables such as temperature and population have negative effects in the long term. Thus, it can be deduced from these results that the need to develop long-term conservation measures and strategies for natural resources, especially land cultivated in Tunisia, to improve its fertility. These measures must also be accompanied by policies to adapt to the climate change context in future years. Political measures are necessary in the short term, such as the adoption of a monetary policy to control inflation through the implementation of price control and monitoring instruments throughout the agro-food chain. These measures must also be accompanied by policies to adapt to the climate change context in future years. Political measures are necessary in the short term, such as the adoption of a monetary policy to control inflation through the implementation of price control and monitoring instruments throughout the agro-food chain. A political strategy integrating control instruments for informal trade which helps to control the increase in prices of basic foodstuffs to maintain the balance between supply and demand without shortage of these goods sometimes on the internal market. In terms of opening the Tunisian economy to the outside world, the return to a strategy aimed at reducing food imports to encourage national production by granting specific subsidies to Tunisian farmers in disadvantaged regions for the cultivation of their agricultural land. Encouraging Tunisian agriculture can also be a source of job creation for young specialized graduates to modernize agriculture using the appropriate new technology and contribute to food security in Tunisia in the medium and long term.

\section{References}

Alam M.M., Siwar C., Molla R.I., Mohd Ekhwan T., Talib B., 2011. Climate Change and Vulnerability of Paddy Cultivation in North-West Selangor, Malaysia: A Survey of Farmers' Assessment. Voice of Academia, 6(1): 45-56.

ADB (Asian Development Bank), 2012. Food security and Poverty in Asia and the Pacific: Key Chal- lenge and Policy Issues. Mandaluyong City, Philippines: Asian Development Bank.

Aker J., Lemtouni A., 1999. A framework for assessing food security in face of globalization: The case of Morocco. Agroalimentaria, 8: 13-26.

Amaza P.S., Adejobi A.O., Fregrene T., 2008. Measurement and determinants of food insecurity in Northeast Nigeria: Some empirical policy guideline. Journal of Food Agriculture and Environment, 6: 92-96.

Amjath-Babu T.S., Aggarwal P.K., Vermeulen S., 2019. Climate action for food security in South Asia? Analyzing the role of agriculture in nationally determined contributions to the Paris agreement. Climate Policy, 19(3): 283-298.

Baffoe-Bonnie J., Gyapong A.O., 2012. The dynamic implication for wages changes on productivity, wages and employment in a developing economy: A structural VAR analysis. The Journal of Developing Areas, 46: 397-417.

Barnett J., Adger W.N., 2007. Climate Change, Human Security and Violent Conflict. Political Geography, 26(6): 639-655. doi:10.1016/j.polgeo.2007.03.003.

Barrett C.B., 2010. Measuring food insecurity. Science, 327(5967): 825-828.

Barrios S., Ouattara B., Strobl E., 2008. The Impact of Climatic Change on Agricultural Production: Is It Different for Africa? Food Policy, 33(4): 287-298.

Bellemare M.F., 2015. Rising Food Prices, Food Price Volatility, and Social Unrest. American Journal of Agricultural Economics, 97(1): 1-21.

Bellemare M.F., Barrett C.B., Just D.R., 2011. The welfare impacts of commodity price volatility: $E v$ idence from rural Ethiopia. Working Paper, Duke University.

Belloumi M., 2014. Investigating the linkage between climate variables and food security in ESA countries. AGRODEP Working Paper 0004.

Bidard C., 2014. Intensive rent and value in Ricardo. Bulletin of Political Economy, 8(2): 99-109.

Breisinger C., van Rheenen T., Ringler C., Nin A., Minot N., Aragon C., Bingxin Y., Ecker O., Tingju Z., 2010. Food security and economic development in the Middle East and North Africa. Current state and future perspectives. IFPRI Discussion Paper 00985. Washington, DC: International Food Policy Research Institute.

Breisinger C., Ecker O., Al-Riffai P., 2011. Économie du printemps arabe. De la révolution à la transformation et la sécurité alimentaire. Politiques alimentaires en perspective, 18: 2-4. 
Chebbi H.E., Lachâal L., 2004. L'agriculture et la sécurité alimentaire : une étude comparative des Pays du Maghreb. New Medit, 3(3): 4-11.

Chuen Khee P., Yet Mee L., Chee Keong C., 2011. The economic impact of climate change on food security in Malaysia. Munich Personal RePEc Archive Paper, 37199, 1-18.

Coates J., 2013. Build it back better: deconstructing food security for improved measurement and action. Global Food Security, 2(3): 188-194.

de Lattre-Gasquet M., Moreau C., Elloumi M., Ben Becher L., 2017, Vers un scénario « Des usages agro-écologiques des terres pour une alimentation diversifiée et de qualité et un système alimentaire territorialisé » en Tunisie en 2050. OCL, 24(3): D306.

Ecker O., Breisinger C., 2012. The food security system. A new conceptual framework. IFPRI Discussion Paper 1166. Washington, DC: International Food Policy Research Institute.

Edame G.E., Ekpenyong A.B., Fonta W.M., Duru E.C., 2011. Climate change, food security and agriculture productivity in Africa: Issues and policy direction. International Journal of Humanities and Social Science, 1(21): 205-223.

Engle R.F., Granger C.W.J., 1987. Co-integration and error correction: Representation, estimation, and testing. Econometrica, 55: 251-276.

FAO (Food and Agriculture Organization), 1996. The state of food and agriculture. Part III, Food security: some macroeconomic dimensions. Rome: Food and Agriculture Organization.

FAO (Food and Agriculture Organization), 2006. Food security. Policy brief, 2. Rome: FAO's Agriculture and Development Economics Division (ESA).

Gana A., 2012. The Rural and Agricultural Roots of the Tunisian Revolution: When Food Security Matters. International Journal of Sociology of Agriculture and Food, Research Committee on Sociology of Food and Agriculture (RC40), 13 p. https://halshs.archives-ouvertes.fr/halshs-01165135.

Gebre G.G., 2012. Determinants of food insecurity among households in Addis Ababa city, Ethopia. Interdisciplinary Description of Complex System, 10: 159-173.

IAASTD (International Assessment of Agricultural Knowledge, Science and Technology for Development), 2009. Agriculture at a Crossroads: Global Report. Washington, DC: Island Press, 98 p.
Krishnamurthy K., Lewis K., Choularton R.J., 2012. Climate impacts on food security and nutrition: A Review of existing knowledge. Exeter: Met Office and WFP's Office for Climate Change, Environment and Disaster Risk Reduction.

Kumar A., Sharma P., 2013. Impact of Climate Variation on Agricultural Productivity and Food Security in Rural India. Economics Discussion Papers, No 2013-43. Kiel: Kiel Institute for the World Economy.

Lacirignola C., Adinolfi F., Capitanio F., 2015. Food security in the Mediterranean countries. New Medit, 14(4): 2-10.

Lagi M., Bertrand K.Z., Yaneer B.Y., 2011. The Food Crises and Political Instability in North Africa and the Middle East. Cambridge, MA: New England Complex Systems Institute.

Malthus T.R., 1815, An inquiry into the nature and the progress of rent and the principles by which it is regulated. London: John Murray (reed in The pamphlets of Thomas Robert Malthus. New York: A.M. Kelly, 1970).

Ojo E.O., 2004. Public Opinion and the Conduct of Nigeria's Foreign Policy: Two Selected case studies, The Nigerian Journal of the Social Sciences, 3(1).

Osei Mensah J., Aidoo R., Tuffour T., 2013. Determinants of household food security in the Sekyere-Afram plains district of Ghana. Global Advanced Research Journal of Agricultural Science, 2(1): 34-40.

Ouertani E., Laajili I., Stambouli T., Benalaya A., 2016. Gestion de l'eau en industrie agroalimentaire tunisienne et son impact sur l'environnement et sur la sécurité alimentaire. LARHYSS Journal, 28: 199-217.

Ricardo D. (1815). The Influence of a Low Price of Corn on the Profits of Stock. London: John Murray. van Eldik C., 2012. The Challenge of Food Security. Through The Trees. Objective, concise and straightforward information examining global environmental issues and research. http://wellearthopedia. blogspot.com/2012/10/the-challenge-of-food-security.html.

Warr P., 2014. Food Insecurity and its Determinants. Australian Journal of Agricultural and Resource Economics, 58(4), 519-537.

World Bank (2011) Food Price Watch. Washington, D.C.: World Bank Group. https://www.worldbank.org/en/topic/poverty/publication/food-pricewatch-home. 